\section{WILLIAM HARVEY}

William Harvey

The Man, The Physician, and The Scientist. By Kenneth D. Keele. (British Men of Science.) Pp. xi $+244+18$ plates. (London: Thomas Nelson and Sons, Ltd., 1965.) 42s. net.

WILLIAM HARVEY: The Man, The Physician, and The Scientist is one of the "British Men of Science" series and is in no sense a biography, although it contains some biographical details. It is divided into three parts: Harvey the man, Harvey the physician, and Harvey the scientist. The first part contains such biographical details as are needed in this study. Harvey's career as a physician is presented fully and in an interesting way.

The main bulk of the book is devoted to Harvey the scientist and easily transcends in both interest and excellence the other two parts. De Motu Cordis is discussed and presented in many aspects, including the previous idoas of the functions of the heart and blood. Harvey's great book is presented and analysed in a way that makes the relevant chapters almost a companion to the work. Especially valuable is the chapter on Harvey's scientific methods, a theme which is continued throughout several chapters and becomes of great interest. Another chapter deals with the reception of Harvey's theory of the circulation of the blood; a discussion of particular interest when we can study the campaign with hindsight.

After De Motu Cordis the author deals thoroughly with De Generatione Animalium and again hindsight makes survey of the problems much easier. Especially interesting is Harvey's conclusion that fortilization of the ovum is due to some process he calls a "contagion, much the same way as medical men observe contagious diseases such as leprosy, lues venerea, plague, phthisis, creep through the ranks of men, and by mere extrinsic contact excite diseases similar to themselves".

This theme, that inevitably leads to and is explained by the spermatozoon and by bacteria, had to await the revelations of the microscope.

The author concludes inevitably that De Generatione compares unfavourably with De Motu Cordis. The essence of the contrast lies in the experimental basis of the one as opposed to the philosophical basis of the other. This is developed in a fascinating chapter on Harvey's scientific lineage, on his place in the history of discovery.

The neglect of the elinical application of Harvey's discovery is well presented and its gradual recovery through the work of Stephen Hales and the progress from Priestley's work to Lavoisier's recognition and description of oxygen and his finding of carbon dioxide in the expired air. The elucidation of the function of the pulmonary circulation thus opens the way for the clinical understanding of the whole circulation. The introduction of the Fick principle carries us further forward until Forssman's and Cournand's work on cardiac catheterization brings us near to the time when "we are at last reaping the fruits of this discovery in terms of the diagnosis of cardiac disease and treatment of the patient".

Dr. Keele concludes his invaluable book with a significant paragraph: "The true essence of greatness lies in the conquest of time. And as we now leave Harvey we can see this little sallow-faced man with the bright eyes standing like a colossus astride the great space of 2,300 years, with one foot in the ancient Greek library of Aristotle, and the other in the operating theatre of the modern cardiac surgeon".

This is an excellent book which I strongly recommend. It should be read by all those interested in the circulation, either physiological or clinical; it is much more than an essay in the history of medicine.

\section{CONSERVATION : WHAT IS IT ?}

Readings in Resource Management and Conservation Edited with Introductions by Ian Burton and Robert W. Kates, with the assistance of Lydia Burton. Pp. xi +609 . (Chicago and London: University of Chicago Press, 1965.) 8.50 dollars; $63 s$.

W HEN will someone write a text-book on conservation and resource management that draws its examples and conclusions from British situations and experience and is written in simple and straightforward English? The question is prompted by two unconnected statements in the admirably succinct preface to Readings in Resource Management and Conservation, in which the editors explain their aim. It is "to acquaint students in courses in conservation and resource management with some of the wide variety of material to be found outside the standard texts" available in the United States and Canada. In Britain, where broadly based courses in conservation and resource management are a novelty to be counted on the fingers of one hand, there is not a single wide-ranging text-book available that has been written with the British student in mind. That such a book is required is undoubted; if one may quote from Burton and Kates (out of context) it should seek to provide "an adequate conceptual framework for resource management and conservation"--a field that is "wide, varied and amorphous". Existing (American) texts have not been notably successful in this particular endeavour, either in content or expression.

Readings in Resource Management and Conservation is an anthology of writings on conscrvation and the "social and behavioural science" aspects of resource management. It incorporates a wide range of selections of historical interest-including polemical statements of the type so difficult to present in traditional text-books-and papers on topics at present of concern in the United States, as well as some not readily accessible or fugitive material. All this has been arranged, and to some extent selected, in such a way as to resemble a monograph more than a text, short bridge-passages providing a linking introduction to each new chapter. This treatment is extremely effective and the editors have undoubtedly, as they express it, "taken a step towards a conceptualization of a field which lacks structure and form as it also lacks theory". (Incidentally, it was this sentence that inspired the second half of the question with which this review opened. Far too much jargon and unnecessary word-coining are blotting the literature of ecology and conservation; it is time for a cleansing and a return to simple and readily understandable English.)

A short, four-page introduction to the anthology traces the pattern of its contents: in the papers selected, "man is seen variously as a biological population, an exploiter, a conserver and a manager of resources; as an economic optimizer, a nature lover and in many other guises". Nature also is variously regarded: "now as an impersonal foree that moulds the destinies of man, now as a complex web of life arranged in a delicate balance that we disturb at our peril, now as a malleable set of resources that $\mathrm{ray}$ be used at will". The selections present a diversity of views ranging from the determinist extreme-“"Malthusian in its concern with the adequacy of resources and conservationist in its prescription for policy"-to the attitude towards Nature that is "optimistic in its view of technological advance and the sufficiency of resources" and concerns itself mainly with the technical and managerial problems of development.

Part 1 of the book, "The Malthusian Equation", considers the problem of population growth and the finite earth; Part 2 is concerned with "The Conservation of Limited Resources"; Part 3 with "The Managenent of an Expanding Resource Base". Particularly revealing of much loose thinking are the selections in Part 2 which deal with the growth of the conservation movement and 